\title{
Diversity of mushrooms in Dry Dipterocarp forest at Phuphan National Park, Sakon Nakhon Province
}

\author{
Pithak Wongchalee, C. Pukahute \\ Department of Biological Science, Faculty of Science, Ubon Ratchathani University, Ubon Ratchathani, Thailand; \\ Corresponding Author: seeharpu@,ubu.ac.th
}

Received 24 August 2012; revised 28 September 2012; accepted 11 October 2012

\section{ABSTRACT}

The purposes of this study were, 1) to study the variety of mushrooms grown in the Dry Dipterocarp forest during the year 2008-2009 by Releve method, 2) to study the relationship between Shoreasia mensis Miq. And Ectomycorrhizal of the Amanitaceae and the Belotaceae families, and 3) study the sequencesof DNAsinsome types of mushrooms in the Amanitaceae and the Balotaceae families by the PCR method. The findings of the study were as thefollowings: First, they were totally 34 types of mush-rooms found in Dry Dipterocarp forest at the Phuphan National Park during the studying period, 20082009. There were 26 types found in both years Amanita hemibapha subsp. javanica Corner \& Bas, A. princeps Corner \& Bas, A. umbrinolutea (Secr. ex Gillet) Bataille, Termi-tomycesmicrocarpus (Berk. \& Br.) R. Heim, T. perforans Heim, T. striatus $\mathrm{f}$. griseus Heim, Boletellusananas (M. A. Curtis) Murrill, B. grisei-purpureus Cor., B. edulis Bull. ex Fr., B. luridus Schaeffer ex Fr., AlpovatrappeiFogel, Can-tharelluscibarius Fries, Craterellusaureus Berk. \& Curis, Astraeushygrometricus (Pers.) Morgan, Lactariusaquifluus Peck, L. glaucescens Crossl., L. piperatus (Scop. ex Fr.) S. F. Gray, L. vellereus (Fr.) Fr., L. virescens Fr., R. densifolia (Secr.) Gill, R. emetica (Schaeff. \& Fr.) S. F. Gray., R. xelempelina (Schaeff.) Fr., R. foetens (Pers.) Fr., R. rosacea (Pers. ex Secr.) Fries, R. violeipes Quél., R. virescens (Schaeff.) Fries. and those found only in $\mathbf{2 0 0 9}$ were Bo-letuscurtisii M. A. Curtis, B. nobilis Peck, RussulaalboareolataHongo, R. cyanoxantha (Schaeff. ex Secr.) Fr. The mushrooms that had been found had significantly relations to the surrounding physical conditions. Second, there was a relationship between the Shoreasiamensis Miq. and Amanita princeps Cor.\& Bas., Amanita hemibapha (Berk. \& Br.) Sacc. subsp. javanica. Cor. \& Bas., Boletus chrysenteron Bull., Boletus griseipurpureus Cor. and Heimiellarestipora (Pat \& Bek.) Boedijn. at the intensity of spores 500, 5000, 50,000 per each. From the SPSS for ANOVA analysis, the Shoreasiamensis Miq. had no relations to Amanita princeps Cor. \& Bas., Amanita hemibapha (Berk. \& Br.) Sacc. subsp. javanica. Cor. \& Bas., Boletus chrysenteron Bull., Boletus grisei-purpureus Cor. and Heimiellarestipora (Pat \& Bek.) Boedijn. in height and circumference growths of Shoreasiamensis Miq. seedlings at the intensity of spores 500, 5000 and 50,000 per each Shoreasiamensis Miq. at $95 \%$ level of confidence. Finally, by using the BLASTN computer program toexamine, compare and separate the differences 4 types of mushrooms' DNA in the Amanitaceae and the Boletaceae families subjected to the PCR method, there were 4 findings i.e. 1342 DNA sbp. of Amanita princeps, 880 DNAs pb. of Boletusnobitis Peck, 1381 DNAs pb. of Boletus edulis Bull. exFr and 758 DNAs bp. of Heimiellaresipora (Pat \& Baker).

Keywords: The Diversity; Mushroom; The Dry Dipterocarp Forest; The Phuphan National Park

\section{INTRODUCTION}

There are several edible well known mushrooms naturally growing in the dry Dipterocarp forest at the Phuphan National Park whilst a few types are poisonous. Most of the mushrooms are in the Actomycorrhizal family which growing as saprobes and parasites. [1] Ectomycorrhizal fungi (ECM) are vital component of forest biodiversity and play a part in forest restoration. Those in the symbiotic type which growing around many plants' roots provide water, minerals to their host plants, moreover, they help protect the hosts from many pathogens. Up until now, there are still less studies on mushroom 
morphological characters which are inadequate to obviously classify types of mushrooms, so molecular techniques studies are needed to classify mushrooms' species, those of the Amanita and Boletus families in particularly.

As the result, it remains less explanation and knowledge about mushrooms made published, whether it be the relationship between mushrooms and other plants, the physical factors are favourable to mushrooms' growth, and etc.

\section{MATERIALS AND METHODS}

\subsection{Collecting Sites}

The mushrooms were collected from Phuphan National Park village forest in Sakon Nakhon Province. The site was in Dry Diptercarp forest.

\subsection{Collecting Methods}

The samples were collected randomly from every stage of ages in two experimental areas sized $100 \times 100$ $\mathrm{m}^{2}$ and $1000 \times 10 \mathrm{~m}^{2}$ during January-December in 20082009. Young mature and old individual fruiting bodies were collected with chisel soil were removed with a fine brush and placed in brown paper bags in a basket, while data of associated host, temperature humidity and intensity of light at the study were recorded. The mushroom collected in study sites and roadside markets nearby the study sites were noted and some interest species were also bought for examination. The tissue of all specimens was kept in $1.5 \mathrm{ml}$ microcentrifuge tube poured in $300 \mu \mathrm{l}$ $2 \mathrm{X}$ CTAB buffer at $-20^{\circ} \mathrm{C}$. Specimens were dried at $45^{\circ} \mathrm{C}-50^{\circ} \mathrm{C}$ overnight and kept in plastic boxes with silica gel to keep out humidity.

\subsection{Taxonomy Methods}

The mushrooms were tentatively identified by a conventional morphology method presented by [1,2] and chemical methods using the keys that provided by [3-5] was employed to classify their chemical characteristics. The latter method was used as the main way to assemble mushrooms in the Basidiocarp family, physical features and basidiospore.

\subsection{Culture and Edibility Information of Some Edible and Wild Boletes}

The fresh sporocarps of mushroom especially the edible species were cultured for vegetative mycelium. A pure culture of each collection was isolated from the issue (small pieces that cut from section between the pileus and strip) using half strength Potato Dextrose Ager (PDA) plate. The pure culture was incubated at room temperature $\left(28^{\circ} \mathrm{C} \pm 2^{\circ} \mathrm{C}\right)[6]$.

\subsection{DNA Extraction}

A small tissue from the flesh section between the pileus and stipe of fruit body was cut with a sterilized knife and placed into a $1.5 \mathrm{ml}$ centrifuge tube containing 300 $\mu 12 \mathrm{X}$ CTAB buffer and kept in $-20^{\circ} \mathrm{C}$ for DNA extraction. The specimens were ground with $200 \mathrm{mg}$ of sterilized quartz sand then $2 \mathrm{X}$ CTAB extraction buffer were added for adjusted to $600 \mu \mathrm{l}$. Contents were then incubated at $60^{\circ} \mathrm{C}$ in a water bath for 30 min with gentle swirling. The solution was then extracted two or three times with an equal volume of chloroform: isoamyl (24:1) at $13,000 \mathrm{rpm}$ for $30 \mathrm{~min}$ until no interface was visible. The supernatant phase containing the DNA was precipitated by addition of 2.5 volumes of absolute ethanol and kept at $-20^{\circ} \mathrm{C}$ overnight. The DNA pellet was washed (70\% ethanol) 2 times, dries (under vacuum), and resuspended in TE buffer ( $1 \mathrm{mM}$ EDTE, $10 \mathrm{mM}$ Tris-HCL, $\mathrm{pH}$ 8) and mixed together with RNase A (1 mg/ml $\left.{ }^{-1}\right)$. In addition some tissues specimens were extracted for DNA by using DNA extract Kits (NucleoSpin ${ }^{\circledR}$ Plant II, Macherey Nagel, Catalog no, 740770.50) following manufaturer's protocal.

\subsection{PCR Amplification Anf Sequencing of 28S rDNA and ITS}

Approximately 900 nucleotides at the 5' end of the nuclear large ribosomal subunit gene (28S rDNA) were amplified by OPERON primer pairs LROR (5'-ACCC GCTGAACTTAAGC-3') and LR5 (5'-TCCTGAGGGA AAACTTCG-3') [7]. A portion of the ITS region was performed by using a pair of universal primer ITS5 (5'GGAAGTAGTCGTAACAAGG-3') and ITS4 (5' - TCCT CCGCTTATTGATATGC-3') (OPERON) [8].

Genomic DNA $3 \mu \mathrm{l}$ was used in a standard $50 \mu \mathrm{M}$ PCR mixture (25 mM MgCl $2,10 \mathrm{MG}$-free buffer, 2.5 $\mu \mathrm{M}$ dNTPs, $1.5 \mu \mathrm{M}$ primers, and 1.5 unit of Taq DNA Polymerase-BioLabs M0267-S) under the following thermal condition: $94^{\circ} \mathrm{C}$ for $30 \mathrm{~s}, 35$ cycles of $94^{\circ} \mathrm{C}$ for $30 \mathrm{~s}, 60^{\circ} \mathrm{C}$ for $30 \mathrm{~s}$, and $72^{\circ} \mathrm{C}$ for $1.5 \mathrm{~min}$. Amplicons were checked on $1 \%$ agarose gels stained with ethidium bromide under UV light. Negative control reaction omiting DNA were included in all sets of amplifications to monitor potential contamination by exogenous DNA. PCR products were purified using NecleoSpin ${ }^{\circledR}$ Extract II PCR clean-up Kit (Macherey Nagel, Catalog no. 740609.50) following manufacturer's protocol. Te amplified 28S rDNA and ITSs fragments were directly sequenced. Sequencing reaction was performed and sequences determined automatically by Macrogen Company in Korea using PCR primer mentioned upper part.

\section{RESULTS}

Knowledge of Mushroom diversity is important 
Table 1. Species classifications and distribution of the identified mushroom present.

\begin{tabular}{|c|c|c|c|c|c|c|c|c|}
\hline \multirow[b]{2}{*}{ Sciencetific name } & \multicolumn{8}{|c|}{ Physical and Biological Characteristic } \\
\hline & $\begin{array}{c}\text { Humidy } \\
\text { (\%) }\end{array}$ & $\begin{array}{c}\text { Temp. } \\
\left({ }^{\circ} \mathrm{C}\right)\end{array}$ & $\begin{array}{l}\text { Light } \\
\text { (Lux) }\end{array}$ & $\mathbf{p H}$ & $\begin{array}{c}\text { Weight } \\
\text { (g) }\end{array}$ & $\begin{array}{l}\text { Wide } \\
\text { (cm) }\end{array}$ & $\begin{array}{l}\text { High } \\
(\mathrm{cm})\end{array}$ & Month \\
\hline Amanita hemibapha subsp. javanica Corner \& Bas & 85 & 30 & 770 & 7.2 & 40 & 6.5 & 7 & Jan-Sep \\
\hline Amanita princeps Corner \& Bas & 67 & 30 & 1600 & 7.2 & 40 & 7 & 10 & Jan-Sep \\
\hline Amanita umbrinolutea (Secr. ex Gillet) Bataille & 85 & 30 & 1030 & 7 & 20 & 4 & 8 & Apl-Nov \\
\hline Termitomyces microcarpus (Berk. \& Br.) R. Heim & 80 & 28 & 1550 & 7 & 30 & 9.7 & 73.2 & May-Dec \\
\hline Termitomyces perforans Heim & 75 & 28 & 450 & 7 & 14 & 1.77 & 15 & May-Sep \\
\hline Boletellus ananas (M. A. Curtis) Murrill & 92 & 30 & 700 & 6 & 70 & 8 & 9.27 & May-Sep \\
\hline Boletus campestris A. H. Smith \& Thiers & 93 & 28 & 1552 & 7 & 40 & 6.62 & 8.7 & Jul-Aug \\
\hline Boletus curtisii M. A. Curtis & 80 & 30 & 789 & 7 & 50 & 2.5 & 5.5 & Jul-Oct \\
\hline Boletus edulis Bull. ex Fr. & 92 & 30 & 201 & 7 & 108 & 7.5 & 5.4 & Jul-Oct \\
\hline Boletus luridus Schaeffer ex Fr. & 90 & 29 & 1000 & 7.2 & 30 & 1.77 & 5 & Jan-Oct \\
\hline Boletus nobilis Peck & 94 & 30 & 150 & 7 & 15 & 2.5 & 1 & Sep-Oct \\
\hline Heimiella retispora (Pat. \& Bak.) Boedijn & 96 & 28 & 950 & 7.1 & 60 & 5.7 & 3.77 & Jul-Aug \\
\hline Boletus griseipurpureus Cor. & 54 & 29 & 1800 & 8.9 & 90 & 5 & 5 & Jul-Oct \\
\hline Russula emetic (Schaeff. \& Fr.) S. F. Gray. & 77 & 30 & 800 & 7 & 20 & 6.7 & 3.77 & Mar-Aug \\
\hline Russula xelempelina (Schaeff.) Fr. & 75 & 30 & 450 & 7.1 & 60 & 4.5 & 3.0 & Jul-Aug \\
\hline Russula foetens Fr. & 60 & 31 & 460 & 7.2 & 40 & 5.77 & 3.5 & Jul-Aug \\
\hline Russula rosacea (Pers. ex Secr.) Fries & 69 & 31 & 1000 & 7.1 & 30 & 5.77 & 5.5 & Jul-Sep \\
\hline Russula virescens (Schaeff.) Fries & 92 & 29 & 350 & 7 & 30 & 14.6 & 3.77 & Jul-Aug \\
\hline Russula violeipes Quél. & 90 & 30 & 376 & 6 & 60 & 4.0 & 2.78 & Jul-Aug \\
\hline Alpova trappei Fogel & 74 & 30 & 197 & 6.5 & 15 & 2.5 & 1 & Jul-Aug \\
\hline Cantharellus cibarius Fries & 78 & 29 & 200 & 7.2 & 55 & 5.27 & 4 & Apl-Nov \\
\hline Craterellus aureus Berk. \& Curis & 76 & 30 & 150 & 7.1 & 25 & 2.5 & 4.7 & Apl-Nov \\
\hline Astraeus hygrometricus (Pers.) Morgan & 60 & 31 & 395 & 6.5 & 15 & 1.5 & 2.13 & Apl-Nov \\
\hline Lentinus polychrorus Lév. & 57 & 30 & 750 & 7 & 26 & 3.2 & 1 & Apl-Nov \\
\hline Microporus xanthopus (Fr.) Kuntze & 78 & 31 & 1200 & 6 & 45 & 4.4 & 3 & Apl-Nov \\
\hline Lactarius aquifluus Peck & 79 & 30 & 470 & 7.1 & 30 & 3 & 2.87 & Jul-Aug \\
\hline Lactarius glaucescens Crossl. & 79 & 29 & 700 & 7.1 & 30 & 2.5 & 3 & Apl-Nov \\
\hline Lactarius piperatus (Scop. ex Fr.) S. F. Gray & 90 & 28 & 512 & 7 & 50 & 3.7 & 2.4 & Jan-Sep \\
\hline Lactarius vellereus (Fr.) Fr. & 70 & 31 & 350 & 7.1 & 50 & 7 & 1.77 & Jul-Aug \\
\hline Lactarius virescens Fr. & 93 & 28 & 713 & 6 & 50 & 3.7 & 2.4 & May-Nov \\
\hline Russula alboareolata Hongo & 75 & 30 & 450 & 7 & 50 & 7 & 1.77 & Jan-Sep \\
\hline Russula cyanoxantha (Schaeff. ex Secr.) Fr. & 55 & 30 & 370 & 7.2 & 30 & 3.7 & 2 & Jul-Aug \\
\hline Russula densifolia (Secr.) Gill & 86 & 29 & 400 & 6.5 & 40 & 4.0 & 3 & Jul-Aug \\
\hline
\end{tabular}

Jan = January; Feb = February; Mar = March; Apl = April; May = May; Jun = June; Jul = July; Aug = August; Sep = September; Oct $=$ October; Nov = Novem ber; Dec $=$ December. 


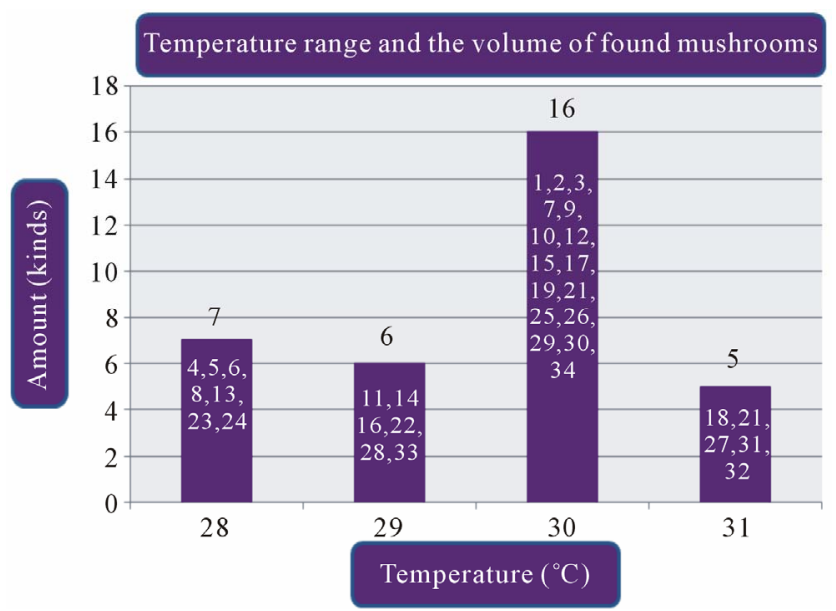

(a)

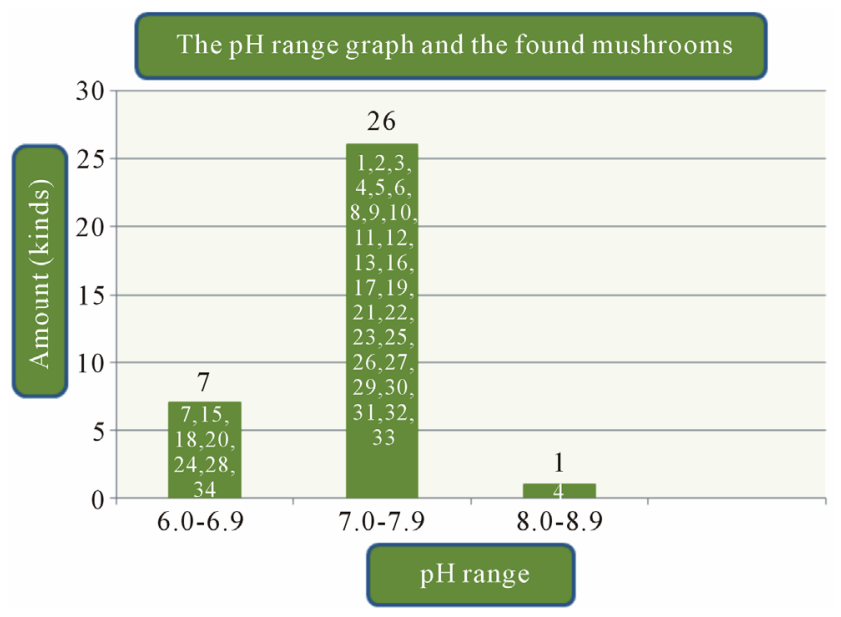

(c)

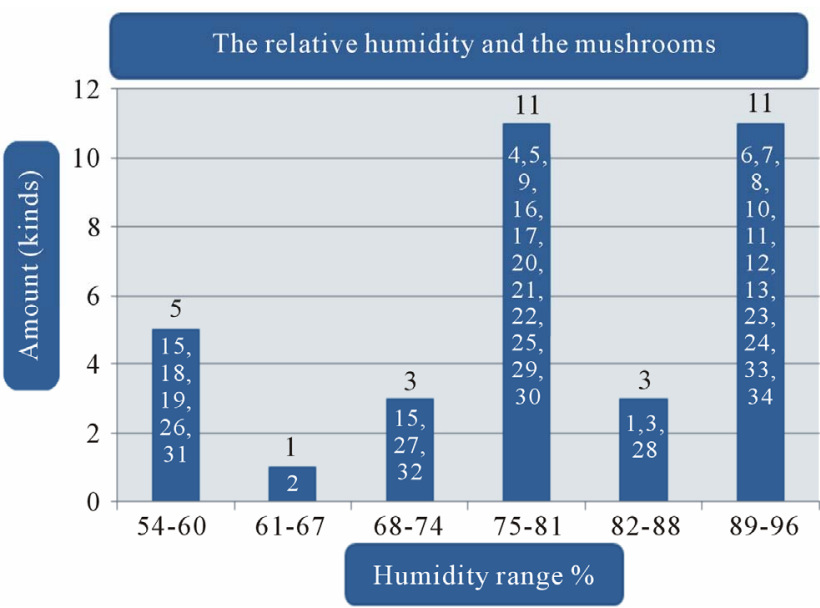

(b)

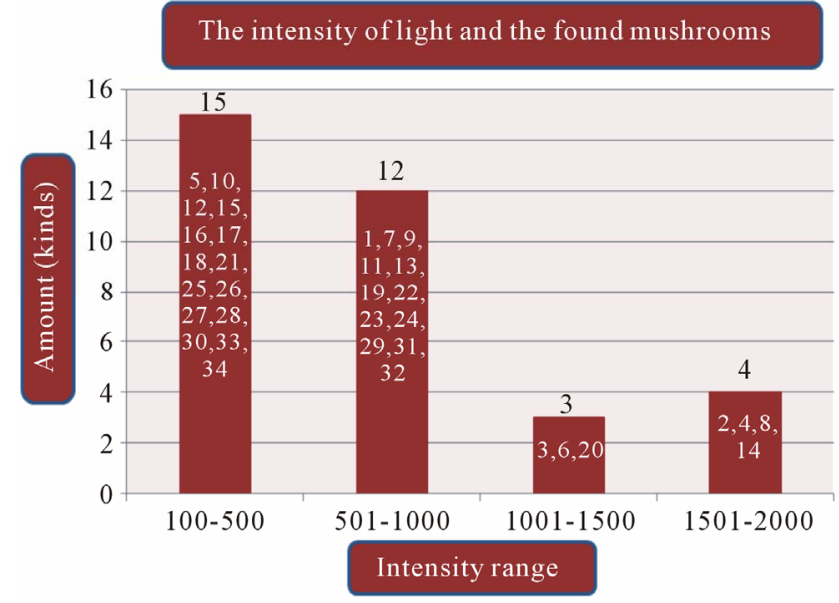

(d)

Figure 1. (a) Temperature range and the volume of found mushrooms; (b) The relative humidity and the mushrooms in the dry dipterocarp forest; (c) The $\mathrm{pH}$ range graph and the found mushrooms; (d) The intensity of light and the found mushrooms. $1=$ Amanita hemibapha (Berk. et Broome) sacc Subsp. javanica Corner et Bas; 2 = Amanita princeps Corner et Bas; 3 = Amanita umbrinoluted; $4=$ Termitomyces microcarpus (Berk. et Broome) Hiem; $5=$ Termitomyces perforans Heim; $6=$ Termitomyces straiatus Heim F. griseus Heim; 7 = Boletellus ananus (M.A. Curtis) Murrill a; $8=$ Boletus campestris; $9=$ Boletus curtsii Curtis; $10=$ Boletus edulis Bull. ex Fr; 11 = Boletus luridus Schaeffer; 12 = Boletus nobilis Peck; $13=$ Heimiella retispora (Pat. \& Baker) Boedijn; $14=$ Tylopilus plumbeoviolaceus (Snell \& Dick); $15=$ Russula emetic (Schaeff. \& Fr.) S. F. Gray; $16=$ Russula fageticola (Melzer); $17=$ Russula foetens Fr.; $18=$ Russula rosacea Pers Ex S.F. Gray; $19=$ Russula virescens (Schaeff.) Fr; $20=$ Russula violeipes Quiel; $21=$ Alpova trappei Fogel; 22 = Cantharellus cibarius Fr.; 23 = Cantharellus aureus Berk. \& Curt; 24 = Astraeus hygrometricus (Pers.) Morgan; $25=$ Lentinus polychrlus Lev.; 26 = Microporus xanthopus (Fr.) Kuntze; 27 = Lactarius aquifluus Peck.; 28 = Lactarius glaucescecs Crossl.; 29 = Lectavius Piperatus (Scop. ex. Fr) S. F. Gray.; 30 = Lectavius virescens Fr.; 31 = Russula adusta (Pers ex Fr.) Fries.; $32=$ Russula albidula Peck; 33 = Russula alboareolata Hongo.; 34 = Russula densifolia (Secr.) Gill.

because of their major roles in natural and managed ecosystems as ectomycorrhizal fungi. The fungal group becomes an important factor for reforestation program worldwide. Furthermore, they are important as food source for human beings and animals [9]. In addition fungal diversity as well as mushroom can also be used as a bio-indicator of environmental quality. Studies on the diversity and taxonomy (base on morphological characters and molecular analyses) of mushroom and other macro and other macro-fungi of Thailand are interested and need more investigation.
This study aims to complete the study of diversity and molecular relations of some stripe-tubulate mushroom collected from reserved rainforest in The Phuphan National Park, Sakhon Nakhon Province.

\section{Diversity of Mushroom in Phuphan National Park, Sakhon Nakhon Province}

The result of this study provided overviews of the diversity and molecular phylogeny of ectomycorrhizal mushroom in The Phuphan National Park, Sakhon Nak- 
hon Province. Approxmimately 34 collections were recorded in The Phuphan National Park, Sakhon Nakhon Province over a two-year period from 2008 to 2009 during wet and cool dry season (January to November). Species classifications and distribution of the identified mushroom present in Table 1.

The study found that the first, there are a variety of mushrooms in dry dipterocarp forest on 2008-2009 at Phuphan national park, found 34 species in total. There were 26 types found in both years Amanita hemibapha subsp. javanica Corner \& Bas, A. princeps Corner \& Bas, A. umbrinolutea (Secr. ex Gillet) Bataille, Termitomyces microcarpus (Berk. \& Br.) R. Heim, T. perforans Heim, T. striatus f. griseus Heim, Boletellus ananas (M. A. Curtis) Murrill, B. griseipurpureus Cor., B. edulis Bull. ex Fr., B. luridus Schaeffer ex Fr., Alpova trappei Fogel, Cantharellus cibarius Fries, Craterellus aureus Berk. \& Curis, Astraeus hygrometricus (Pers.) Morgan, Lactarius aquifluus Peck, L. glaucescens Crossl., L. piperatus (Scop. ex Fr.) S.F. Gray, L. vellereus (Fr.) Fr., L. virescens Fr., R. densifolia (Secr.) Gill, R. emetica (Schaeff. \& Fr.) S.F. Gray., R. xelempelina (Schaeff.) Fr., R. foetens (Pers.) Fr., R. rosacea (Pers. ex Secr.) Fries, R. violeipes Quél., R. virescens (Schaeff.) Fries. The mushroom types found only in 2008 were Boletus campestris A.H. Smith \& Thiers, Heimiella retispora (Pat. \& Bak.) Boedijn, Lentinus polychrorus Lév., Microporus xanthopus (Fr.) Kuntze and those found only in 2009 were Boletus curtisii M. A. Curtis, B. nobilis Peck, Russula alboareolata Hongo, R. cyanoxantha (Schaeff. ex Secr.) Fr. The mushrooms that had been found had significantly relations to the surrounding physical conditions, 22 species were found at the temperature range $29^{\circ} \mathrm{C}-30^{\circ} \mathrm{C}$ (min $28^{\circ} \mathrm{C}$, $\max 31^{\circ} \mathrm{C}$, average $29^{\circ} \mathrm{C}$ ) as shown in Figure 1(a), most mushrooms (28 species) were found at the relative humidity range between $68 \%$ - 96\% ( $\min 54 \%$, max $96 \%$, the average relative 75\%) as shown in Figure 1(b), 26 species found at $\mathrm{pH}$ range $7.0-7.9$ ( $\min 6$, max 8.9, average 7) as shown in Figure 1(c), and 16 species found at the light intensity range of $150-500$ lux (min 150, max 1800, average 970) as shown in Figure 1(d).

The second, there is a relationship between the Shorea siamensis Miq. and Amanita princeps Cor. \& Bas., Amanita hemibapha (Berk. \& Br.) Sacc. subsp. javanica. Cor. \& Bas., Boletus chrysenteron Bull., Boletus griseipurpureus Cor. and Heimiella restipora (Pat \& Bek.) Boedijn. at the intensity of spores 500, 5000, 50,000 per each-From the SPSS for ANOVA analysis, the Shorea siamensis Miq. had no relations to Amanita princeps Cor. \& Bas., Amanita hemibapha (Berk. \& Br.) Sacc. subsp. javanica. Cor. \& Bas., Boletus chrysenteron Bull., Boletus griseipurpureus Cor. and Heimiella restipora (Pat \& Bek.) Boedijn. in height and circumference growths of Shorea siamensis Miq. seedlings at the intensity of spores 500, 5000 and 50,000 per each Shorea siamensis Miq. at $95 \%$ level of confidence.

The third, by using the BLASTN computer programme to examine, compare and separate the differences 4 types of mushrooms' DNA in the Amanitaceae and the Boletaceae families subjected to the PCR method, there were 4 findings i.e. 1342 DNAs bp. of Amanita princeps, 880 DNAs pb. of Boletus nobitis Peck, 1381 DNAs pb. of Boletus edulis Bull. ex Fr and 758 DNAs bp. of Heimiella resipora (Pat \& Baker). The modern science can effectively identify types of mushrooms of the Amanita family as well as the difference levels of the molecule of each type of mushrooms [10-16].

\section{REFERENCES}

[1] Kirk, P.M., Camnon, P.E., Davidand J.C. and Stalpers J.A. (2001) Dictionary of the Fungi. 9th Edition, CABI Publishing, Wallingford.

[2] Smithe, F.B. (1975) Naturalist's color guide. The American museum of natural history, New York.

[3] Corner, E.J.H. (1972) Boletus in Malaysia. Government Printing Office, Singapore.

[4] Moser, M. (1983) Key to Agarics and Boleti. Roger Phillips Publication.

[5] Ellis, M.B. and Ellis, J.P. (1990) Fungi without Gills (Hymenomycetes and Gasteromycetes) An identification Handbook. Chapman and Hall, London.

[6] Lumyong, S., Sanmee, R. and Lumyong, P. (2007) Is large scale cultivation of boletes possible? Opera Mycilogica, $\mathbf{1}$, 34-37.

[7] Vilgalys, R. and Hester, M. (1990) Rapid genetic identification and mapping of enzymatically amplified ribosomal DNA from several Cryptococcus species. Journal of Bacteriology, 172, 4239-4246.

[8] White, T.J., Bruns, T., Lee, S. and Taylor, J. (1990) Amplification and direct sequencing of fungal ribosomal RNA genes for phylogenetics. In: Innis, M.A., Gelfand, D.H., Sninsky, J.J. and White, T.J., Eds., PCR Protocols, A Guide to Methods and Applications, Academic Press, New York, 315-322.

[9] Brundrett, M., Bougher, N., Dell, B., Grove, T. and Malajczuk, N. (1996) Working with mycorrhizas in forestry and agriculture. Australian Centre for International Agricultural Research, Canberra.

[10] Felsenstein, J. (1985) Confidence limits on phylogenics: An approach using the bootstrap. Evolution, 6, 227-242.

[11] Hall, T.A. (1999) BioEdit: A user-friendly biological sequence alignment editor and analysis program for Windows 95/98/NT. Nucleic Acids Symposium Series, 41, 95-98.

[12] Huelsenbeck, J.P. and Ronquist, F. (2001) MRBAYES: Bayesian inference of phylogenetic trees. Bioinformatics, 17, 754-755. doi:10.1093/bioinformatics/17.8.754

[13] Mueller, G.M., Schmit, J.P., Huhndorf, S.M., Ryvarden, L., O’Dell, T.E., Lodge, D.J., Leacock, P.R., Mata, M.M., 
Umna, L., Wu, Q.X. and Czederpilt, D. (2004) Recommended protocols for sampling macrofungi. In: Mueller, G.M., Bills, G. and Foster, M.S., Eds., Biodiversity of fungi: Inventory and Monitoring Methods. Elsevier Academic Press, San Diego.

[14] Nylander, J.A.A. (2004) MrModeltest v2. Program distributed by the author. Uppsala University, Uppsala.
[15] Swofford, D.L. (2002) PAUP. Phylogenetis analysis using parsimony. Sinauer Associates, Sunderland. http://www.sinauer.com/detail.php?id=8060

[16] Tamura, K., Dudley, J., Nei, M. and Kumar S. (2007) Molecular evolutionary genetics analysis. Molecular Biology and Evolution, 24, 1596-1599. doi:10.1093/molbev/msm092 


\section{APPENDIX}

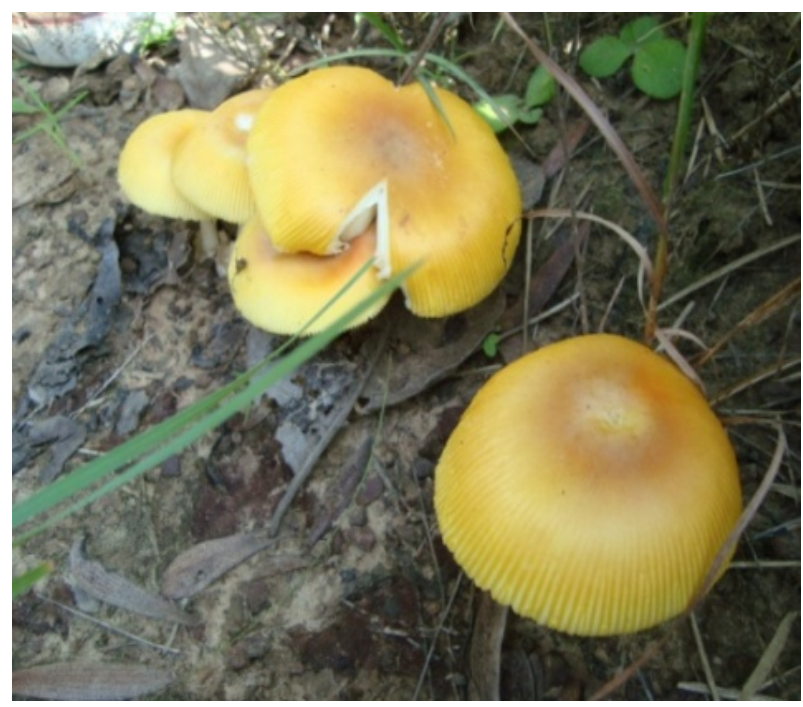

Amanita hemibapha (Berk.et Broome) sacc. Subsp. javanica Corner et Bas.

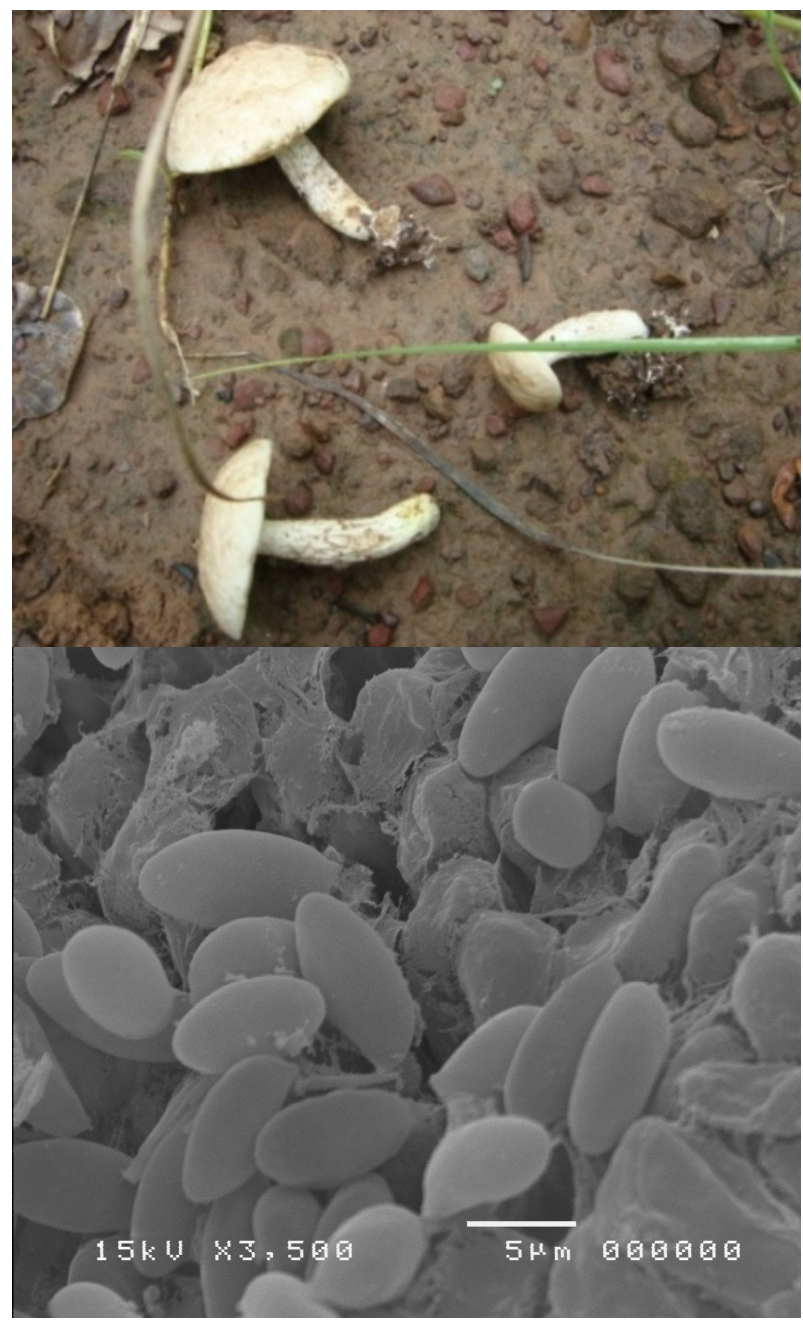

Boletus campestris.

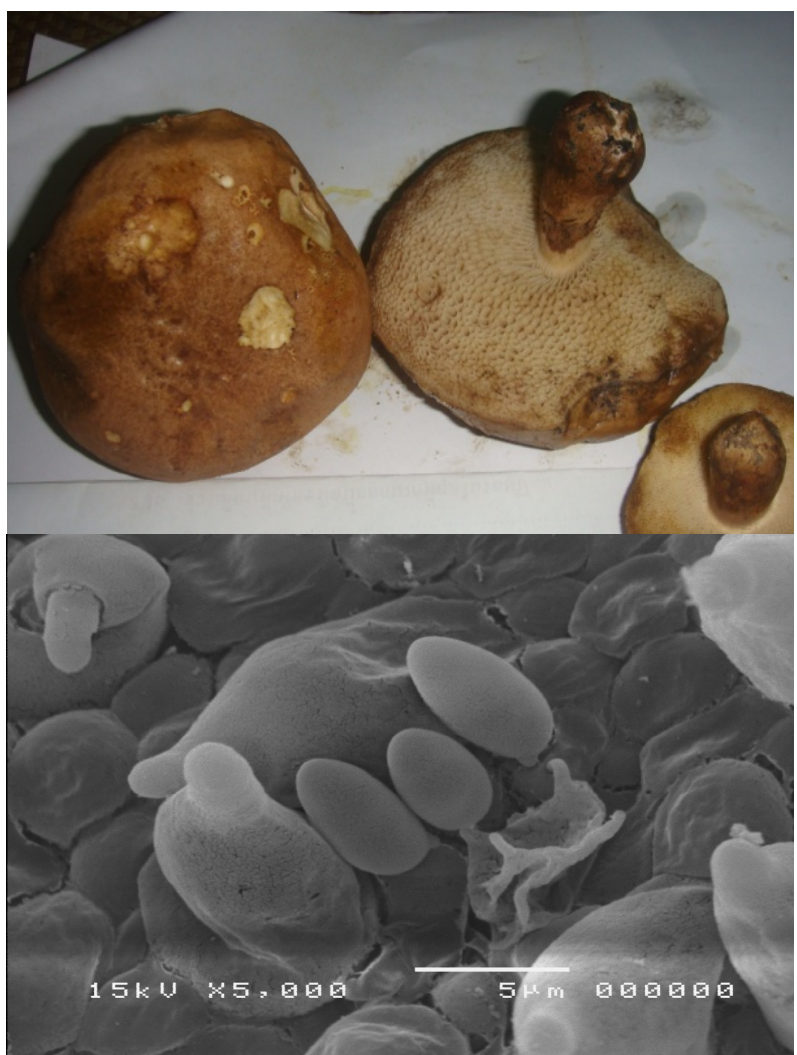

Boletus edulis Bull. ex Fr.

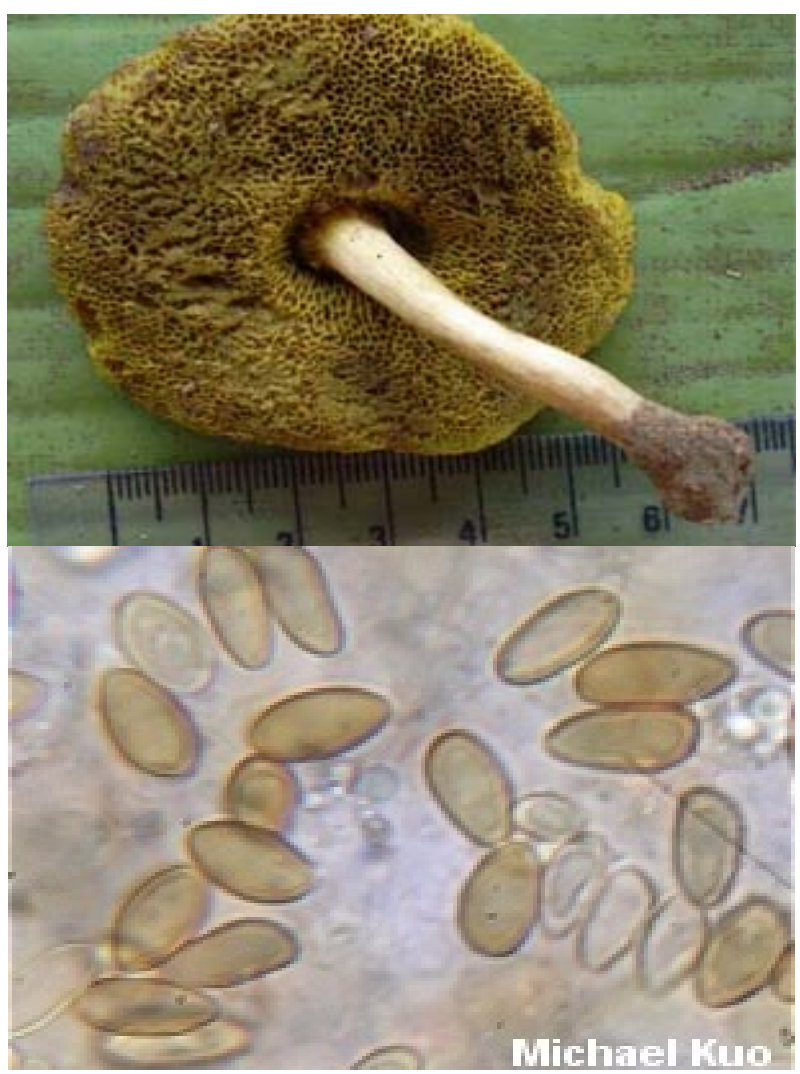

Boletus luridus Schaeffer. 


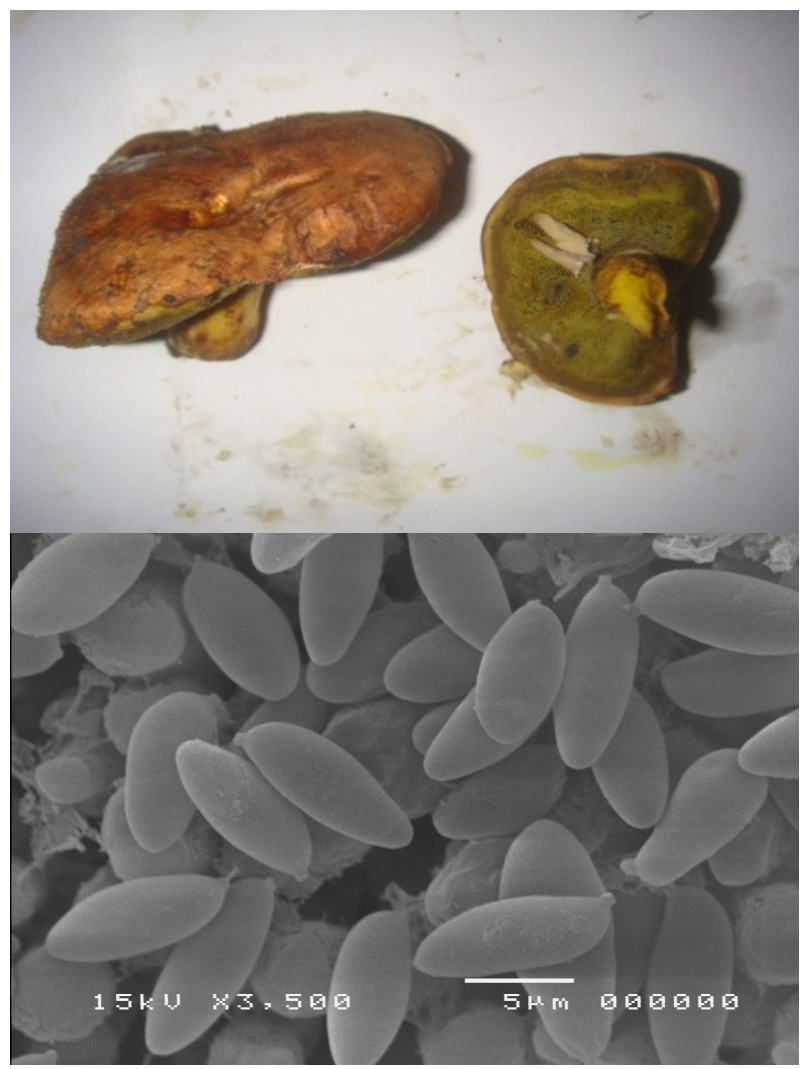

Boletus nobilis Peck.

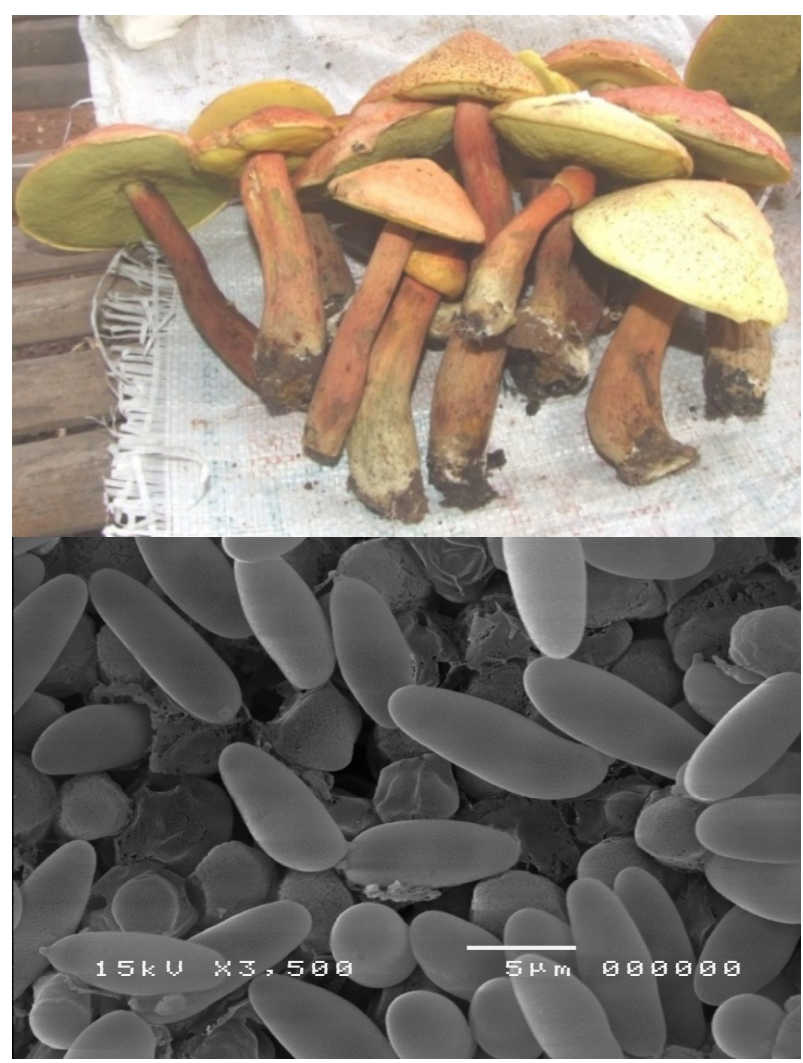

Heimiella retispora (Pat. \& Baker) Boedijn.

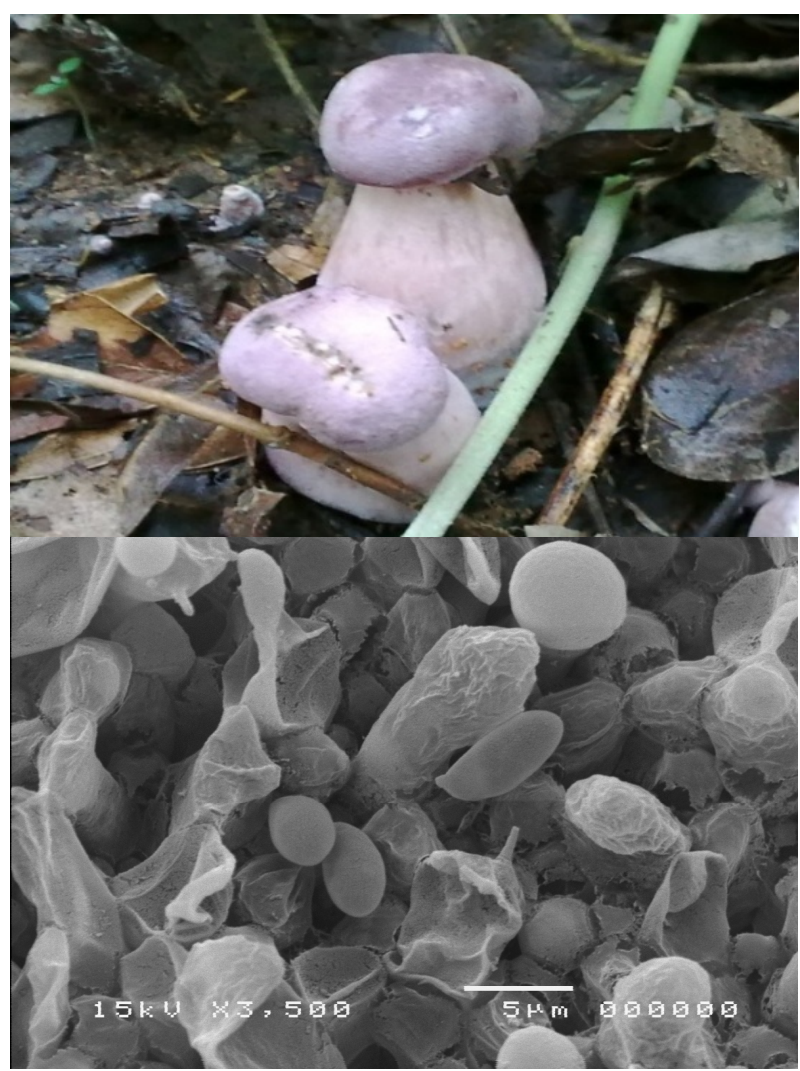

Tylopilus plumbeoviolaceus (Snell \& Dick).

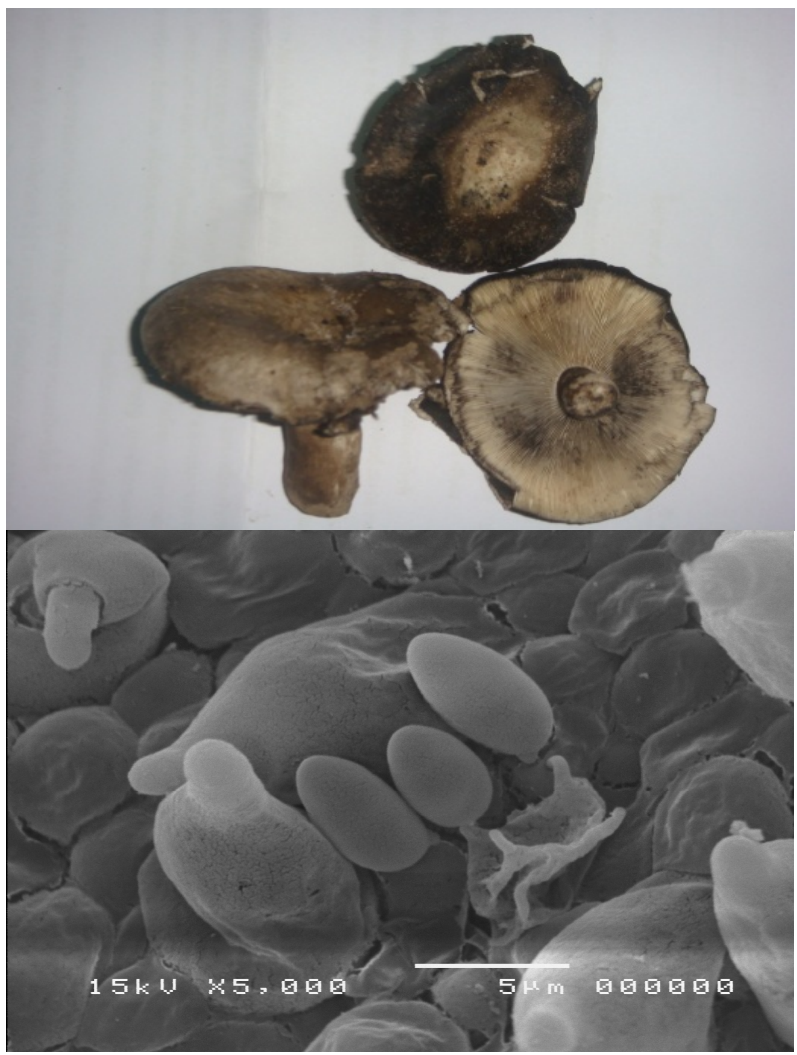

Russula densifolia (Secr.) Gill. 